\title{
Fusarium and Aspergillus mycotoxins effects on dairy cow health, performance and the efficacy of Anti-Mycotoxin Additive
}

\author{
J. Jovaišienė, B. Bakutis, V. Baliukonienė, G. Gerulis \\ Department of Food Safety and Quality, Veterinary Academy of Lithuanian University of Health Sciences, \\ Tilžès 18, LT-47181 Kaunas, Lithuania
}

\begin{abstract}
One hundred two samples of feeds made in Lithuania, which included maize silage, grass-legume silage, hay and ensiled crimped maize were investigated during 2008-2012 for contamination with some mycotoxins. The highest concentrations of mycotoxins determined were those of deoxynivalenol $(\mathrm{DON})-471.0 \mu \mathrm{g} / \mathrm{kg}$ and aflatoxin $\mathrm{B}_{1}\left(\mathrm{AFB}_{1}\right)-21.2 \mu \mathrm{g} / \mathrm{kg}$ in ryegrass silage from bales, and zearalenone (ZEA) $-625.0 \mu \mathrm{g} / \mathrm{kg}$ in maize silage from trenches. The present study has been carried out based on these data because animal feeds contaminated with mycotoxins can cause reduced productivity of dairy cows and health disorders in the long term. The aim of this study was to investigate the long-term exposure of toxic effects of a diet naturally contaminated with low concentrations of mycotoxins on milk composition and biochemical, hematological, immunological parameters of dairy cows and to determine the anti-mycotoxin effect of Mycofix Plus 3.E. Twenty eight clinically healthy, medium productive Lithuanian Red cows were selected. ZEA was a major contaminant found in the corn silage at concentration levels of up to $1000.0 \mu \mathrm{g} / \mathrm{kg}$ of dry matter. DON was the second major found in the hay at concentration levels of up to $600.0 \mu \mathrm{g} / \mathrm{kg}$ of dry matter. The highest concentration $\mathrm{AFB}_{1}-10.0 \mu \mathrm{g} / \mathrm{kg}$ was determined in ground barley. The Anti-Mycotoxin Additive (AMA) Mycofix Plus 3.E was given individually to 14 cows at a concentration of $40.0 \mathrm{~g}$ daily for 9 weeks.

The present results indicate that feeds naturally contaminated with low concentration of mycotoxins produced by Fusarium spp. and Aspergillus spp. in a diet of dairy cows can have a negative influence on somatic cell count, blood parameters and immunity. The addition of an Anti-Mycotoxin Additive (Mycofix Plus 3.E) to diet of dairy cows can prevent many of these effects.
\end{abstract}

Key words: Anti-Mycotoxin Additive, mycotoxins, dairy cows, blood parameters, milk composition 


\section{Introduction}

Molds are filamentous (fuzzy or dusty looking) fungi that occur in many feedstuffs including roughages and concentrates. Molds can infect dairy cattle, especially during stressful periods when they are immune suppressed, causing a disease referred to as a mycosis. Molds also produce poisons called mycotoxins that affect animals when they consume mycotoxin contaminated feeds. This disorder is called a mycotoxicosis (Whitlow 2005). It is generally accepted that the Aspergillus, Fusarium and Penicillium molds are among the most important in producing mycotoxins detrimental to cattle. The mycotoxins of the greatest concern include: aflatoxins, which are generally produced by Aspergillus mold; deoxynivalenol, zearalenone, T-2 toxin, fumonisins, which are produced by Fusarium molds; ochratoxins produced by Penicillium molds. There are hundreds of different mycotoxins which are diverse in their chemistry and have effects on animals. It is likely that contaminated feeds will contain more than one mycotoxin (Whitlow and Hagler 2002). In order to protect animal health some countries have recommendations for deoxynivalenol, ochratoxin A, fumonisins and zearalenone content in feed (European Commission 2006, Rasmussen et al. 2011).

Little is known about the effects of feedborne Fusarium, Aspergillus, Penicillium mycotoxins and their synergisms on the performance, hematological and biochemical blood parameters, and milk composition of dairy cattle. The data concerning the effects of mycotoxin-contaminated diets on health and performance of dairy cows are still rare. Studies by Danicke et al. (2005), and Seeling et al. (2006) showed that DON concentrations ranging between 3.1 and $3.5 \mathrm{mg} \mathrm{g}^{-1}$ feed ( $88 \%$ DM) did not cause any significant adverse health effects but transiently increased post-prandial ammonia concentrations (Fink Grammels 2008). Fink Grammels (2008) found correlation between the capacity of the rumen to inactivate mycotoxins and the likelihood of adverse health effects in cattle. A chronic exposure to low levels of mycotoxins typically gives non-specific symptoms such as an impaired immune system and increased infections or metabolic and hormonal imbalances (Morgavi and Riley 2007, Fink-Gremmels 2008, Rasmussen et al. 2011).

Nature has provided ruminants with a distinct ability to detoxify and degrade mycotoxins present in feed in the form of ruminal microflora and microfauna; however, this ability is saturable (Khatoon 2012). The effect of mycotoxins on the performance, metabolism, and immunity in dairy cattle was demonstrated elsewhere. Those adverse effects on health are unexpected and commonly associated with dose de- pendence and a long exposure. High-yielding cattle, especially during a transition period, are prone to be more sensitive to mycotoxins than fatting cattle (Chaiyotwittayakun 2010). Different factors like metabolic disorders (rumen acidosis, milk fever, etc.), abrupt change in diet, a high protein diet, negative energy balance, antimicrobial activity of some mycotoxins, etc. can decrease the detoxifying ability of ruminal microflora (Khatoon 2012).

An alternative approach to reducing the exposure to mycotoxins in feed is decreasing the bioavailability by the inclusion of mycotoxin detoxifying agents (mycotoxin detoxifiers) in the feed. This method is most commonly used today (Devreese et al. 2013). A frequently used method for controlling mycotoxicosis is the use of material nutritionally inherent to the animals' diet, in order to decrease the absorption of mycotoxins in the gastrointestinal tract. These substances were called mycotoxin adsorbent and are now generically called Anti-Mycotoxin Additives (AMA) (Mallmann et al. 2009). Favourable results have been observed when absorbent materials such as clays (bentonites), complex indigestible carbohydrates such as glucomannans or mannanoligiosaccharides and other similar products are added to mycotoxin contaminated diets of rats, poultry, swine and cattle (Whitlow 2005).

The aims of this study were to investigate the long-term exposure of toxic effects of diet naturally contaminated with low concentrations of mycotoxins on biochemical, hematological, immunological parameters and milk composition of dairy cows and to determine the effect of Mycofix Plus 3.E.

\section{Materials and Methods}

\section{Experimental animals and diets}

A total of 28 Lithuanian Red dairy cows of different parities (approximately $25 \%$ primiparous and $75 \%$ of multiparous, randomly assigned in groups) were used in the experiment (14 cows per trial). The cows were in third lactation, the duration of the lactation was $122 \pm 15.9$ days. The milk-yield of cows was $15.36 \mathrm{~kg} / \mathrm{d}$., an average of milk fat was $4.14 \pm 0.25 \%$, protein content $3.06 \pm 0.04 \%$ and urea $-23.80 \pm 1.35$ $\mathrm{mg} \%$. The diets were fed for 63 days and included two groups. The first group was control (CG) - a naturally contaminated diet. The second group was experimental $(\mathrm{EG})$ - a naturally contaminated diet +40 g per day for cow Mycofix ${ }^{\circledR}$ Plus 3.E (mineral components, biological constituent, live organism, phytogenic substances, phycophytic constituents). Barley, silage, haylage and hay were the sources of 
Table 1. Diets composition.

\begin{tabular}{|c|c|c|c|c|}
\hline \multirow{2}{*}{ Ingredients } & \multicolumn{2}{|c|}{ Naturally contaminated (TMR) } & \multicolumn{2}{|c|}{$\begin{array}{c}\text { Naturally contaminated } \\
\text { TMR + Mycofix }{ }^{\circledR} \text { Plus 3.E }\end{array}$} \\
\hline & $\begin{array}{l}\text { As fed, } \mathrm{kg} / \mathrm{cow} \\
\text { per day }\end{array}$ & $\begin{array}{l}\mathrm{DM}, \mathrm{kg} / \mathrm{cow} \\
\text { per day }\end{array}$ & $\begin{array}{l}\text { As fed, } \mathrm{kg} / \mathrm{cow} \\
\text { per day }\end{array}$ & $\begin{array}{l}\mathrm{DM}, \mathrm{kg} / \mathrm{cow} \\
\text { per day }\end{array}$ \\
\hline $\begin{array}{l}\text { Silage (oats, feeding pease, lucerne) } \\
(31.0 \% \text { of DM) }\end{array}$ & 35.0 & 10.85 & 35.0 & 10.85 \\
\hline $\begin{array}{l}\text { Haylage (lucerne and cocksfoot) } \\
(35.12 \% \text { of DM) }\end{array}$ & 35.0 & 12.29 & 35.0 & 12.29 \\
\hline $\begin{array}{l}\text { Hay (perennials, different botanical } \\
\text { composition grasses) }(93.1 \% \text { of DM) }\end{array}$ & 5.0 & 4.66 & 5.0 & 4.66 \\
\hline Ground barley $(90.0 \%$ of DM) & 18.0 & 16.20 & 18.0 & 16.20 \\
\hline Mycofix $^{\circledR}$ Plus 3.E & - & - & 0.04 & 0.04 \\
\hline Total TMR & 93.0 & 44.00 & 93.0 & 4.04 \\
\hline
\end{tabular}

Table 2. Effect of diets on health and performance of dairy cows.

\begin{tabular}{lcccc}
\hline \multicolumn{1}{c}{ Cows group } & Temperature ${ }^{\circ} \mathrm{C}$ & Puls rate (per minute) & $\begin{array}{c}\text { Respiratory rate } \\
\text { (breaths/minute) }\end{array}$ & $\begin{array}{c}\text { Rumen contraction } \\
\text { rate }(\text { per 2 minutes) }\end{array}$ \\
\hline $\begin{array}{l}\text { CG } \\
\text { Mean } \pm \text { SE }\end{array}$ & $38.48 \pm 0.005$ & $67.04 \pm 0.32$ & $19.05 \pm 0.19$ & $3.99 \pm 0.04$ \\
\hline $\begin{array}{l}\text { EG } \\
\text { Mean } \pm \text { SE }\end{array}$ & $38.45 \pm 0.007$ & $69.2 \pm 0.22$ & $20.20 \pm 0.17$ & $4.01 \pm 0.05$ \\
\hline $\begin{array}{l}\text { Reference } \\
\text { values (Sutkevičius, 2003) }\end{array}$ & $37.50-39.00$ & $50.00-80.00$ & $10.00-30.00$ & $2.00-5.00$ \\
\hline
\end{tabular}

CG - control group; EG- experimental group

feedborne mycotoxins, the experimental diets were prepared locally and formulated according to energy requirements for dairy cows. The total mixed ration (TMR) is documented in Table 1.

Chemical composition (crude proteins, lipids, soluble sugars and starch, NDF, ADF, ash) of silage, haylage and hay, ground barley samples after drying, were determined by laboratory analysis with NIRS. Metabolizable energy (ME), net energy for lactation (NEL) and fermentation were calculated according to VDLUFA (Germany) methodology. Amounts of dry matter (DM) in feeds were individually recorded at once before the trial. The samples were oven-dried at $105^{\circ} \mathrm{C}$ for $48 \mathrm{~h}$ and the percentage of DM calculated.

\section{Animals health}

During the trial period the cows were housed in group pens according to their feeding group, with individual feeders. The feed and water were provided ad libitum. The cows were milked twice a day in their stalls without daily exercise.

The experiment proceeded without any noticeable incidents. The health status of the cows was regularly checked by a veterinarian, as documented in Table 2 . Acute mastitis occurred during the trial just sporadically, once in the control and once in the experimental groups as it was treated, this disease should not be over-interpreted in the present experiment.

\section{Analysis of feedborne mycotoxins}

Dietary contents of $\mathrm{AFB}_{1}, \mathrm{ZEA}$ were analyzed by Thin-layer chromatography (TCL) and described by Romer Labs Inc. ${ }^{\circledR}$ Method (Code: a/z-tl-01-00.2) and deoxynivalenol (DON) (Code: CAM-000031-1). All samples of feeds were dried at $70^{\circ} \mathrm{C}$ for $24 \mathrm{~h}$ in an oven, ground to pass a $1 \mathrm{~mm}$ screen. Twenty five grams of each sample was extracted with $100 \mathrm{ml}$ acetonitrile/DI water $(84 / 16, \mathrm{v} / \mathrm{v})$ solution for $3 \mathrm{~min}$ into a blender. The extract was filtered through Whatman $\mathrm{N}^{\circ} 4$ filter paper (Whatman, Inc., Clifton, New Jersey, USA).

Analysis of $A F B_{1}, Z E A$ concentrations: $90 \mu \mathrm{L}$ of glacial acetic acid was added to $9 \mathrm{~mL}$ of the filtrate and mixed well. Clean-up columns MycoSep ${ }^{\circledR}$ 226AflaZon+Multifunctional columns (Romer Labs, Inc. Union, MO, USA) were used for cleaning the 
extracts, following the methodology supplied by the manufacturer. Two $\mathrm{mL}$ of the extract were evaporated using the Romer Evap ${ }^{\mathrm{TM}}$ System. The residue was dissolved in $300 \mu \mathrm{L}$ toluene/acetonitrile (97/3, v/v). $90 \mu \mathrm{L}$ of sample and standards $\left(10,20,40,80 \mu \mathrm{L}-\mathrm{AFB}_{1}\right.$ spotting standard: $0.05 \mu \mathrm{g} / \mathrm{mL}$ and $15,30,60 \mu \mathrm{L}$ of $5 \mu \mathrm{g} / \mathrm{mL}$ ZEA working standard) were spotted onto the TLC Silica gel 60 F254 plate with the AutoSpotter $^{\mathrm{TM}}$ (Romer Labs TLC, AutoSpotter, Model 10). The matrixs were prepared by adding $48 \mu \mathrm{L}$ of $\mathrm{AFB}_{1}$ spiking standard $\left(0.625 \mu \mathrm{g} / \mathrm{mL}\right.$ each of $\left.\mathrm{AFB}_{1}\right)$ and 90 $\mu \mathrm{L}$ of $25 \mu \mathrm{g} / \mathrm{mL}$ ZEA spiking standard to $9 \mathrm{~mL}$ of $84 / 16$ acetonitrile/water. Plate was developed of $\mathrm{AFB}_{1}$ and ZEA in $9 / 1(\mathrm{v} / \mathrm{v})$ chloroform/acetone. The plate was viewed under a long wave of UV light. ZEA appeared light green with an $\mathrm{Rf}$ (retention factor) of approximately $0.9, \mathrm{AFB}_{1}$ appeared blue and has an $\mathrm{Rf}$ of approximately 0.45 . The plate was spread with $15 \%$ aluminum chloride in methanol. The plate was viewed again under UV light. ZEA appeared blue. The plate was spread with $10 \%$ sulfuric acid in methanol. The plate was viewed again under UV light. $\mathrm{AFB}_{1}$ appeared yellow.

Analysis of DON concentration: $10 \mathrm{ml}$ of extract was transferred into a tube, pushed slightly over $4 \mathrm{~mL}$ through a MycoSep ${ }^{\circledR} 225$ Trich column (Romer Labs, Inc. Union, MO, USA). Four $\mathrm{mL}$ of purified extract was transferred to the preconditioned MultiSep ${ }^{\circledR} 216$ column (Romer Labs, Inc. Union, MO, USA) and collected. The extract has drained through MultiSep ${ }^{\circledR}$ 216 Trich column rinse with $12 \mathrm{~mL}$ of $84 / 16$ acetonitrile/DI water and was collected. Evaporated with the Romer Evap ${ }^{\text {TM }}$ System. 100, 200, 300, 400 ng of the TLC spotting standard was spotted on a TLC plate. The residue was dissolved in $400 \mu \mathrm{L}$ of $2 / 1$ acetone/methanol. Eighty $\mu \mathrm{L}$ of sample and matrix spike along with standards were spotted on silica gel TLC plate. The plate was developed with $1 / 2$ toulene/acetone. The plate was sprayed with $15 \%$ aluminum chloride in methanol. The plate was heated at $150^{\circ} \mathrm{C}$ until standard spots were fully visible under a long wave of UV light. DON appears blue with Rf values of approximately 0.5 .

The detection limit was $0.1 \mathrm{mg}(\mathrm{ppm})$ of DON; $200 \mu \mathrm{g}$ (ppb) of ZEA; $1.7 \mu \mathrm{g}$ (ppb) of $\mathrm{AFB}_{1}$.

\section{Milk composition and amount}

Representative samples of milk were taken once a month at the morning milking. The samples were researched in the State enterprise „Pieno Tyrimai”. The milk samples were analyzed for fat, protein, lactose, urea, Somatic Cell Count (SCC) „LactoScope FTIR" (FT1.0. 2001; Delta Instruments, Netherlands).

\section{Blood biochemistry}

Blood samples were collected twice during the trial period: 0 day and 63 days (d.) from the jugular vein before the morning feeding. Blood samples were collected into a tube without any anticoagulant, allowed to clot and after centrifugation serum was produced. The serum was used to test the concentration of phosphorus, magnesium, total protein, albumin, urea, creatinine, glucose, alkaline phosphatase, glutamylt ransferase, aspartate aminotransferase, creatine kinase, alanin aminotransferase and laktat dehydrogenase. The following samples were determined in National Food and Veterinary Risk Assessment Institute's Department of Radiological Research Laboratory (Lithuania), using an automatic biochemical an analyzer „Cobas Integra 400 plus” (Tegimenta Ltd, Roche, Switzerland).

\section{Complete blood count}

Blood samples for complete blood count analyses and leukograma were collected twice during a trial period: $0 \mathrm{~d}$. and $63 \mathrm{~d}$. from the jugular vein before the morning feeding in EDTA-coated blood tubes. Complete blood count for white blood cells, red blood cells, hemoglobin, hematocrit, mean corpuscular volume, mean corpuscular hemoglobin, mean corpuscular hemoglobin concentration, red cell distribution width, platelets, mean packed volume, were determined in the Laboratory of Large Animal Clinic of VA LUHS by the automated differentiation analyzer „Abacus junior vet”. The total leukocyte and the differential leukocyte count were performed with May-Grunwald Giemsa. The percentage of leukocytes was established from the 100 cells count.

\section{Serum Immunoglobulin (IgA) concentrations}

Concentrations of $\operatorname{IgA}$ were determined in serum samples using the Bovine IgA test kit (GenWay Biotech, Inc), which is a highly sensitive two-site enzyme linked immunoassay (ELISA) for measuring IgA in bovine biological samples. The absorbance was measured at a wavelength of $450 \mathrm{~nm}$ on an ELISA reader spectrophotometer.

Statistical analyses were carried out using SPSS software (version 12.0 for Windows, SPSS Inc., Chicago, IL, USA). Values are presented as means \pm standard error (SE) and were considered statistically significant when $\mathrm{p}<0.01$ and $\mathrm{p}<0.05$. 
Table 3. Mycotoxin concentrations in feeds during the trial period.

\begin{tabular}{lccc}
\hline \multicolumn{1}{c}{ Feedstuffs } & \multicolumn{3}{c}{ Mycotoxins } \\
\cline { 2 - 5 } & $\mathrm{AFB}_{1}(\mu \mathrm{g} / \mathrm{kg})$ & $\mathrm{DON}(\mu \mathrm{g} / \mathrm{kg})$ & $\mathrm{ZEA}(\mu \mathrm{g} / \mathrm{kg})$ \\
\hline 1. Silage (oats, feeding pease, lucerne), hay & 6.0 & 350.0 & 550.0 \\
\hline 2. Haylage (lucerne and cocksfoot) & 7.0 & 500.0 & 700.0 \\
\hline 3. Hay (perennials, different botanical composition grasses) & 4.0 & 600.0 & 1000.0 \\
\hline 4. Ground barley & 10.0 & 450.0 & 270.0 \\
\hline
\end{tabular}

Table 4. Effects of cows diets on milk production, milk composition and somatic cell count.

\begin{tabular}{|c|c|c|c|c|c|}
\hline \multirow[b]{2}{*}{ Parameters } & \multirow[b]{2}{*}{ Days } & \multicolumn{4}{|c|}{ Groups } \\
\hline & & $\begin{array}{c}\text { CG } \\
\text { Mean } \pm \text { SE }\end{array}$ & $\begin{array}{c}\text { Effects } \\
\text { of diet**** }\end{array}$ & $\begin{array}{c}\text { EG } \\
\text { Mean } \pm \text { SE }\end{array}$ & $\begin{array}{c}\text { Effects } \\
\text { of diet**** }\end{array}$ \\
\hline Milk production $(\mathrm{kg} / \mathrm{cow})$ & $\begin{array}{c}0 \\
63\end{array}$ & $\begin{array}{l}15.01 \pm 0.98 \\
15.99 \pm 1.71\end{array}$ & 0.28 & $\begin{array}{l}14.14 \pm 1.77 \\
16.06 \pm 1.04\end{array}$ & -0.9 \\
\hline Milk fat (\%) & $\begin{array}{c}0 \\
63\end{array}$ & $\begin{array}{l}4.81 \pm 0.3 \\
4.17 \pm 0.40\end{array}$ & 0.48 & $\begin{array}{l}4.25 \pm 0.59 \\
3.53 \pm 0.15\end{array}$ & $0.72 * *$ \\
\hline Milk proteins (\%) & $\begin{array}{c}0 \\
63\end{array}$ & $\begin{array}{l}3.48 \pm 0.11 \\
3.32 \pm 0.32\end{array}$ & -0.18 & $\begin{array}{l}2.84 \pm 0.33 \\
3.44 \pm 0.08\end{array}$ & $0.58^{*}$ \\
\hline Milk lactose (\%) & $\begin{array}{c}0 \\
63\end{array}$ & $\begin{array}{l}4.61 \pm 0.03 \\
4.47 \pm 0.44\end{array}$ & 0.01 & $\begin{array}{l}3.82 \pm 0.44 \\
4.48 \pm 0.03\end{array}$ & 0.41 \\
\hline Milk urea (\%) & $\begin{array}{c}0 \\
63\end{array}$ & $\begin{array}{l}46.00 \pm 2.25 \\
22.00 \pm 0.43\end{array}$ & 0.11 & $\begin{array}{l}33.07 \pm 4.86 \\
23.36 \pm 1.45\end{array}$ & -0.14 \\
\hline $\mathrm{SCC}$ cells $/ \mathrm{ml} \times 1.000$ & $\begin{array}{c}0 \\
63\end{array}$ & $\begin{array}{l}47.5 \pm 33.39 \\
82.5 \pm 66.08\end{array}$ & $0.8^{* *}$ & $\begin{array}{l}40.9 \pm 4.48 \\
41.07 \pm 4.49\end{array}$ & 0.16 \\
\hline
\end{tabular}

$\mathrm{CG}$ - control group; EG - experimental group.

$* \mathrm{p}<0.05 ; * * \mathrm{p}<0.01 ; * * * r$ value.

\section{Results}

Four feeds in the experimental diets were naturally contaminated with mycotoxins: silage, haylage, hay, barley. The hay contained ZEA as the major contaminant, DON and $\mathrm{AFB}_{1}$ as minor contaminants. ZEA was the major contaminant found in the hay at levels of up to $1000.0 \mu \mathrm{g} / \mathrm{kg}$ of dry matter. DON was another contaminant found in the hay at levels of up to $600.0 \mu \mathrm{g} / \mathrm{kg}$ of dry matter. The highest $\mathrm{AFB}_{1}$ concentration, $10.0 \mu \mathrm{g} / \mathrm{kg}$, was found in ground barley. The analyzed concentrations of feedborne mycotoxins in the diets are given in Table 3.

Milk production and milk composition are presented in Table 4. Milk production ( $\mathrm{kg} / \mathrm{cow})$ increased $12.0 \%(\mathrm{p}>0.05)$ in experimental group and $6.1 \%$ $(p>0.05)$ in the control group after 63 days. Somatic cells count was not significantly increased after $63 \mathrm{~d}$. in the control group.

The results of the blood hematological analyses are presented in Table 5. Most of these parameters were not affected by diets with mycotoxins $\left(\mathrm{AFB}_{1}\right.$, DON, ZEA) and mycotoxins plus Mycofix Plus 3.E. The results of blood count monitored at the beginning and at the end of the research show that there was no deviation from physiological values.

Serum biochemistry profiles for both cows groups are presented in Table 6. According to the data, urea parameter in the control group during the research period was higher than physiological values. Other biochemical parameters in both groups during the research were within the range of physiological values.

The immunity status of dairy cows was influenced due to low mycotoxins concentrations in diet. IgA concentrations were decreased not significantly after $63 \mathrm{~d}$. in the control group and increased in the experimental group.

\section{Discussion}

In dairy cattle, up to $70 \%$ of the diet is composed of concentrates to meet the energy requirements of animals, resulting in possible exposure to more than one type of mycotoxins (Fink-Gremmels 2008). Mycotoxins can also be present in hay, straw and silage after a prolonged period of storage (Mansfield and Kuldau 2007). A high dry matter concentration 
Table 5. Effects of cows diets on hematological values.

\begin{tabular}{|c|c|c|c|c|c|c|}
\hline \multirow[b]{2}{*}{ Parameters } & \multirow[b]{2}{*}{ Days } & \multicolumn{4}{|c|}{ Groups } & \multirow{2}{*}{$\begin{array}{l}\text { Reference } \\
\text { values }\end{array}$} \\
\hline & & $\begin{array}{c}C G \\
\text { Mean } \pm \text { SE }\end{array}$ & $\begin{array}{c}\text { Effects } \\
\text { of diet*** }\end{array}$ & $\begin{array}{c}\text { EG } \\
\text { Mean } \pm \text { SE }\end{array}$ & $\begin{array}{c}\text { Effects } \\
\text { of diet*** }\end{array}$ & \\
\hline White blood cells, $10^{9} / \mathrm{L}$ & $\begin{array}{c}0 \\
63\end{array}$ & $\begin{array}{l}7.12 \pm 0.52 \\
8.76 \pm 0.71\end{array}$ & 0.38 & $\begin{array}{l}10.36 \pm 0.96 \\
10.77 \pm 0.62\end{array}$ & -0.68 & $4.0-12$ \\
\hline GRA, $10^{9} / \mathrm{L}$ & $\begin{array}{c}0 \\
63 \\
\end{array}$ & $\begin{array}{l}2.44 \pm 0.19 \\
3.78 \pm 0.40\end{array}$ & 0.18 & $\begin{array}{l}4.42 \pm 0.71 \\
4.11 \pm 0.38\end{array}$ & -0.19 & $0.6-6.7$ \\
\hline Lymphocytes, \% & $\begin{array}{c}0 \\
63 \\
\end{array}$ & $\begin{array}{l}4.17 \pm 0.11 \\
4.19 \pm 0.33 \\
\end{array}$ & $0.56^{*}$ & $\begin{array}{l}5.05 \pm 0.42 \\
5.74 \pm 0.37 \\
\end{array}$ & 0.43 & $2.5-7.5$ \\
\hline Platelets, $10^{9} / \mathrm{L}$ & $\begin{array}{c}0 \\
63 \\
\end{array}$ & $\begin{array}{c}56.64 \pm 45.06^{*} \\
183.00 \pm 26.37 \\
\end{array}$ & 0.31 & $\begin{array}{l}240.07 \pm 35.69^{*} \\
386.79 \pm 168.39 \\
\end{array}$ & 0.22 & $100-800$ \\
\hline Red blood cells, $10^{12} / \mathrm{L}$ & $\begin{array}{c}0 \\
63 \\
\end{array}$ & $\begin{array}{l}5.56 \pm 0.15 \\
5.96 \pm 0.26 \\
\end{array}$ & $0.68^{* *}$ & $\begin{array}{l}6.09 \pm 0.22 \\
6.63 \pm 0.25 \\
\end{array}$ & 0.5 & $5.0-10.0$ \\
\hline Haematocrit, $\%$ & $\begin{array}{c}0 \\
63 \\
\end{array}$ & $\begin{array}{l}26.81 \pm 0.58 \\
27.63 \pm 0.75 \\
\end{array}$ & 0.22 & $\begin{array}{l}27.78 \pm 0.66 \\
30.30 \pm 1.09 \\
\end{array}$ & 0.27 & $24-46$ \\
\hline Haemoglobin, g/L & $\begin{array}{c}0 \\
63 \\
\end{array}$ & $\begin{array}{l}77.64 \pm 1.95 \\
79.79 \pm 2.70 \\
\end{array}$ & 0.27 & $\begin{array}{l}81.14 \pm 2.23 \\
85.72 \pm 2.44\end{array}$ & 0.51 & $80-150$ \\
\hline Basophilic granuliocytes (BG), \% & $\begin{array}{c}0 \\
63 \\
\end{array}$ & $\begin{array}{l}3.00 \pm 0.93 \\
1.92 \pm 0.50 \\
\end{array}$ & 0.26 & $\begin{array}{l}1.36 \pm 0.31 \\
1.50 \pm 0.20 \\
\end{array}$ & -0.13 & \\
\hline Eosinophilic granuliocytes (EG), \% & $\begin{array}{c}0 \\
63 \\
\end{array}$ & $\begin{array}{l}13.43 \pm 2.30 \\
10.86 \pm 1.79 \\
\end{array}$ & $0.63^{*}$ & $\begin{array}{l}11.71 \pm 2.36 \\
12.64 \pm 2.74 \\
\end{array}$ & 0.27 & \\
\hline Band Neutrophils, \% & $\begin{array}{c}0 \\
63 \\
\end{array}$ & $\begin{array}{l}4.14 \pm 0.66 \\
7.79 \pm 0.97 \\
\end{array}$ & 0.24 & $\begin{array}{l}4.93 \pm 0.75 \\
6.21 \pm 0.97 \\
\end{array}$ & -0.1 & \\
\hline Segmented Neutrophils, $\%$ & $\begin{array}{c}0 \\
63 \\
\end{array}$ & $\begin{array}{l}22.57 \pm 2.57 \\
30.21 \pm 2.63 \\
\end{array}$ & 0.19 & $\begin{array}{l}26.57 \pm 3.31 \\
28.57 \pm 3.29 \\
\end{array}$ & 0.14 & \\
\hline Monocytes, \% & $\begin{array}{c}0 \\
63\end{array}$ & $\begin{array}{l}2.57 \pm 0.68 \\
1.64 \pm 0.32 *\end{array}$ & 0.5 & $\begin{array}{l}1.86 \pm 0.29 \\
1.71 \pm 0.34^{*}\end{array}$ & 0.36 & \\
\hline
\end{tabular}

$\mathrm{CG}$ - control group; EG - experimental group.

${ }^{*} \mathrm{p}<0.05 ; * * \mathrm{p}<0.01 ; * * * r$ value.

$(>50 \%)$ in the raw material makes silage more susceptible to self-heating and infestations with toxin-producing fungi (Purwin et. al 2006). According to the results of Marczuk et al. (2012) study, in the animals exposed to natural low-dose ZEA and DON mycotoxins was observed an acute autoimmune response and immunosuppression, as indirectly confirmed by blood morphological and biochemical tests. In the present study, levels of these mycotoxins were analyzed because they are in the range of the levels commonly found in the feed of dairy cows in Lithuania.

In a field study, diets with about $750.0 \mathrm{ppb}$ ZEA and $500.0 \mathrm{ppb}$ DON resulted in poor consumption, depressed milk production, diarrhea, increase in reproductive tract infections, and total reproductive failure (Whitlow 2005). In the present study, the concentration of milk proteins was significantly higher $17.44 \%(p<0.05)$ in the experimental group of cows, $63 \mathrm{~d}$. after the beginning of the research. In the control group, this parameter was $4.6 \%$ ( $p>0.05)$ lower. The concentration of milk fat was significantly $16.94 \%$ $(\mathrm{p}<0.01)$ lower in the experimental group while in the control group this parameter was not significantly $13.31 \%$ ( $p>0.05$ ) lower, $63 \mathrm{~d}$. after the beginning of the research. The count of somatic cells in the control group was significantly $42.42 \%(\mathrm{p}<0.01)$ higher, while in the experimental group this parameter was not significantly $0.4 \%$ ( $>0.05)$ higher, $63 \mathrm{~d}$. after the beginning of the research. For example, the results from a Canadian study using 18 first-lactation cows during mid-lactation showed that cows consuming DON-contaminated diets (4 to $5 \mathrm{ppm}$ ) produced $13 \%$ less fat corrected milk $(\mathrm{p}<0.16)$ than the cows consuming clean feed (Whitlow 2005).

Literature data point out that lower ZEA levels influence hematological parameters in animals. Gajecka et al. (2004) have established significant ZEA influence on hematological results with regard to the number of erythrocytes and leucocytes, hemoglobin concentration, values of haematocrit and mean cell haemoglobin concentration, and the share of segmented neutrophilic granulocytes and lymphocytes. Fernandez et al. (2000) observed no effects of 
Table 6. Effect of cows diets on serum chemical values and $\operatorname{IgA}$ levels.

\begin{tabular}{|c|c|c|c|c|c|c|}
\hline \multirow[b]{2}{*}{ Parameters } & \multirow[b]{2}{*}{ Days } & \multicolumn{4}{|c|}{ Groups } & \multirow{2}{*}{$\begin{array}{l}\text { Reference } \\
\text { values }\end{array}$} \\
\hline & & $\begin{array}{c}\mathrm{CG} \\
\text { Mean } \pm \mathrm{SE}\end{array}$ & $\begin{array}{c}\text { Effects } \\
\text { of } \operatorname{diet}^{* * *}\end{array}$ & $\begin{array}{c}\text { EG } \\
\text { Mean } \pm \text { SE }\end{array}$ & $\begin{array}{c}\text { Effects } \\
\text { of } \operatorname{diet}^{* * *}\end{array}$ & \\
\hline Total protein, $\mathrm{g} / \mathrm{L}$ & $\begin{array}{c}0 \\
63\end{array}$ & $\begin{array}{l}70.96 \pm 0.84 \\
77.22 \pm 1.12\end{array}$ & 0.70 & $\begin{array}{l}71.35 \pm 1.21 \\
76.00 \pm 1.35\end{array}$ & 0.34 & $70-94$ \\
\hline Albumin, $\mathrm{g} / \mathrm{L}$ & $\begin{array}{c}0 \\
63\end{array}$ & $\begin{array}{l}36.54 \pm 0.47 \\
39.12 \pm 0.86\end{array}$ & 0.25 & $\begin{array}{l}34.54 \pm 0.82 \\
37.98 \pm 0.72\end{array}$ & $0.64^{*}$ & $34-43$ \\
\hline Lactate dehydrogenase, U/L & $\begin{array}{c}0 \\
63 \\
\end{array}$ & $\begin{array}{l}1114.79 \pm 63.47 \\
1270.93 \pm 67.40 \\
\end{array}$ & $0.77^{* *}$ & $\begin{array}{l}1410.36 \pm 93.98 \\
1564.38 \pm 48.66\end{array}$ & $0.64^{*}$ & 308.6-938.1 \\
\hline Aspartate transaminase (AST), IU/L & $\begin{array}{c}0 \\
63 \\
\end{array}$ & $\begin{array}{l}80.27 \pm 4.97 \\
79.30 \pm 4.85 \\
\end{array}$ & $0.74 * *$ & $\begin{array}{c}85.44 \pm 4.74 \\
102.74 \pm 4.76 \\
\end{array}$ & $0.70^{* *}$ & $56.0-176.0$ \\
\hline Alanine transaminase, $\mathrm{U} / \mathrm{L}$ & $\begin{array}{c}0 \\
63\end{array}$ & $\begin{array}{l}24.87 \pm 0.65 \\
28.15 \pm 1.14\end{array}$ & 0.49 & $\begin{array}{l}22.51 \pm 1.14 \\
27.50 \pm 1.09\end{array}$ & $0.75^{* *}$ & $6.9-35.3$ \\
\hline Alkaline phosphatase (ALP), U/L & $\begin{array}{c}0 \\
63\end{array}$ & $\begin{array}{l}45.00 \pm 4.11 \\
50.19 \pm 8.03\end{array}$ & $0.70^{* *}$ & $\begin{array}{l}62.88 \pm 11.94 \\
59.56 \pm 10.61\end{array}$ & $0.86^{* *}$ & - \\
\hline $\begin{array}{l}\text { Gamma-glutamyl transferase (GGT), } \\
\mathrm{U} / \mathrm{L}\end{array}$ & $\begin{array}{c}0 \\
63 \\
\end{array}$ & $\begin{array}{l}24.41 \pm 1.49 \\
29.04 \pm 1.49 \\
\end{array}$ & $0.58^{*}$ & $\begin{array}{l}28.44 \pm 1.49 \\
28.94 \pm 2.28 \\
\end{array}$ & $0.6^{*}$ & - \\
\hline Glucose, $\mathrm{U} / \mathrm{L}$ & $\begin{array}{c}0 \\
63\end{array}$ & $\begin{array}{l}1.73 \pm 0.12 \\
1.87 \pm 0.10\end{array}$ & -0.16 & $\begin{array}{l}1.60 \pm 0.19 \\
1.46 \pm 0.16\end{array}$ & 0.48 & $2.1-3.8$ \\
\hline $\mathrm{Ca}, \mathrm{mmol} / \mathrm{L}$ & $\begin{array}{c}0 \\
63 \\
\end{array}$ & $\begin{array}{l}2.48 \pm 0.03 \\
2.69 \pm 0.05\end{array}$ & 0.14 & $\begin{array}{l}2.30 \pm 0.05 \\
2.75 \pm 0.03\end{array}$ & 0.41 & $2.10-2.7$ \\
\hline P-inorgani, mmol/L & $\begin{array}{c}0 \\
63 \\
\end{array}$ & $\begin{array}{l}2.06 \pm 0.14 \\
2.13 \pm 0.09\end{array}$ & 0.36 & $\begin{array}{l}1.72 \pm 0.16 \\
2.19 \pm 0.11 \\
\end{array}$ & 0.39 & $1.46-2.83$ \\
\hline $\mathrm{Mg}, \mathrm{mmol} / \mathrm{L}$ & $\begin{array}{c}0 \\
63 \\
\end{array}$ & $\begin{array}{l}0.90 \pm 0.03 \\
1.08 \pm 0.03\end{array}$ & 0.05 & $\begin{array}{l}1.03 \pm 0.04 \\
1.07 \pm 0.01\end{array}$ & 0.28 & $0.85-1.2$ \\
\hline Urea, $\mathrm{mmol} / \mathrm{L}$ & $\begin{array}{c}0 \\
63\end{array}$ & $\begin{array}{r}5.03 \pm 0.25 \\
11.71 \pm 6.23\end{array}$ & -0.22 & $\begin{array}{l}4.19 \pm 0.32 \\
6.19 \pm 0.30\end{array}$ & $0.55^{*}$ & $3.0-8.3$ \\
\hline Creatinine, $\mathrm{mmol} / \mathrm{L}$ & $\begin{array}{c}0 \\
63 \\
\end{array}$ & $\begin{array}{l}69.07 \pm 2.67 \\
85.79 \pm 3.59 \\
\end{array}$ & $0.54^{*}$ & $\begin{array}{l}63.14 \pm 3.08 \\
85.50 \pm 2.91 \\
\end{array}$ & $0.59 *$ & $40.0-80.0$ \\
\hline $\operatorname{Ig} \mathrm{A}, \mathrm{ng} / \mathrm{mL}$ & $\begin{array}{c}0 \\
63\end{array}$ & $\begin{array}{l}184.21 \pm 27.35 \\
154.43 \pm 20.98\end{array}$ & 0.06 & $\begin{array}{l}178.86 \pm 30.61 \\
209.07 \pm 27.53\end{array}$ & $0.79^{* *}$ & - \\
\hline
\end{tabular}

* $\mathrm{p}<0.05 ; * * \mathrm{p}<0.01 ; * * * r$ value.

aflatoxin on the hematological parameters of lambs that received high doses of aflatoxin $(2 \mathrm{mg}$ of aflatoxin $/ \mathrm{kg}$ of diet). In the present study, lymphocyte $0.5 \%(p<0.05)$, red blood cell $6.7 \%(p<0.01)$ significantly increased in the control groups of cows $63 \mathrm{~d}$. after the beginning of the research. However, there was no deviation from physiological values. In contrast to our results, Tripathi et al. (2008) observed the reduction of eosinophils count and mean cell haemoglobin concentration and increased haematocrit parameter under daily doses of $\mathrm{AFB}_{1} 50 \mu \mathrm{g} / \mathrm{kg} \mathrm{DM}, 91$ days. In our study, in the experimental group of cows, these parameters were not significantly affected by diets.

The cows fed with mycotoxin-contaminated feeds significantly elevated serum metabolites including urea, protein, aspartate aminotransferase, glutamate dehydrogenase and gamma glutamyl transferase (Chaiyotwittayakun 2010). Serum enzyme activities are generally elevated in mycotoxicosis suggesting mild hepatocellular injury (Pier 1992, Fink Grammels 2008). Serum activities of alkaline phosphatase (ALP), alanine aminotransferase (ALT), aspartate aminotransferase (AST), gammaglutamil transferase (GGT) were estimated to assess liver function. Serum activities of GGT were higher $15 \%(\mathrm{p}<0.05)$ in the control group of cows and in the experimental group of cows $1.7 \%(\mathrm{p}<0.05) 63 \mathrm{~d}$. after the beginning of the research. Serum activities of ALP were significantly $10.3 \%(\mathrm{p}<0.01)$ higher, $63 \mathrm{~d}$. after the beginning of the research in the control group of cows. In the experimental group of cows, ALP activities were significantly lower $5.3 \%(\mathrm{p}<0.01)$ on $63 \mathrm{~d}$. Serum AST activities were significantly $1.2 \%(p<0.01)$ lower in the control group. In the experimental group of cows, AST activities were significantly $16.81 \%(\mathrm{p}<0.05)$ higher $63 \mathrm{~d}$. after the beginning of the research as compared with that found at the start of research. All these par- 
ameters were not higher than the physiological limits in both groups of cows in our study. Tripathi et al. (2008) observed no significant differences in the hepatic enzyme activities (AST, acid and alkaline phosphatase), suggesting that the levels of mycotoxins (aflatoxin) in this study caused only a low and transient negative effect on sheep hepatocytes. Ling et al. (2006) reported that feeding a group of cows with wheat contaminated with Fusarium spp. containing $8.21 \mathrm{mg} \mathrm{DON} / \mathrm{kg} \mathrm{DM}$ and $0.09 \mathrm{mg}$ ZEA $/ \mathrm{kg} \mathrm{DM}$ caused the increase in serum AST, LDH and GGT values conditioned by the amount of ingested dietary mycotoxin.

Urea and creatinine concentrations in blood serum increased and amounted to respectively 57\% $(p>0.05), 19.49 \%(p<0.05)$ in the control and 32.3\% $(p<0.05), 26.17 \%(p<0.05)$ in the experimental groups $63 \mathrm{~d}$. after the beginning of the research. However, the urea concentration was higher $29.12 \%$ than the physiological limit for this animal species in the control groups and this effect was prevented by dietary supplementation with Mycofix Plus 3.E. Danicke et al. (2005) observed that postprandial rumen fluid ammonia concentrations were consistently higher when Fusarium mycotoxin-contaminated wheat was fed to cows. Moreover, the flow of microbial protein and utilizable protein at the duodenum were simultaneously reduced. These results suggest that diets naturally contaminated with DON as the major mycotoxin can alter microbial protein turnover in the rumen (Korosteleva et al. 2007). The present result is in agreement with that obtained by Smith et al. (2007) when the feeding of contaminated with mycotoxins feedstuffs resulted in a continuous elevation in serum urea concentrations throughout the experiment and this effect was prevented by dietary supplementation with GMA.

The albumin and protein levels are further indicators of the liver function (Tripathi et al. 2008). In our study, total serum protein and albumin concentrations were not significantly increased after $63 \mathrm{~d}$. in both groups of cows. However these parameters were not higher than physiological limits. These results are in contrast to those obtained by Korosteleva et al. (2007) who fed cows naturally contaminated feed with DON, ZEA and 15-acetyl-deoxynivalenol, resulting in significant increase in total serum protein concentration.

The reduction in concentrations of serum $\operatorname{IgA}$ in cows fed a contaminated diet illustrates the immunosuppressive effect of Fusarium mycotoxins (Korosteleva et al. 2007). Ingested DON affects intestinal Ig synthesis. Specifically, DON stimulates intestinal IgA production in mice, leading to an elevated concentration of circulating serum (Vahedi 2012). In the present study, Ig A levels in cow serum decreased $16.17 \%$ ( $>0.05)$ in the control group and significantly increased $14.45 \%(\mathrm{p}<0.01)$ in the experimental group 63d. after the beginning of the research. The present result is in agreement with that obtained by Korosteleva et al. (2007), in which declines in total serum IgA were observed in deoxynivalenol, zearalenone and 15-acetyl DON toxin-treated dairy cows.

\section{Conclusions}

The present results indicate that the feed naturally contaminated with low concentration of mycotoxins produced by Fusarium, and Aspergillus spp. in diet of dairy cows can have an influence on somatic cell count, blood parameters and immunity of dairy cows. The feeding of Mycofix Plus 3.E can prevent many of these effects.

\section{References}

Chaiyotwittayakun A (2010) Mycotoxins and health in dairy cattle. In Globalization of tropical animal diseases and public health concerns. Proceedings of the 13th Association of Institutions for Tropical Veterinary Medicine (AITVM) Conference, Bangkok, Thailand, pp 221-223.

Dänicke S, Matthäus K, Lebzien P, Valenta H, Stemme K, Ueberschär KH, Flachowsky G (2005) Effects of Fusarium toxin-contaminated wheat grain on nutrient turnover, microbial protein synthesis and metabolism of deoxynivalenol and zearalenone in the rumen of dairy cows. J Anim Physiol Anim Nutri (Berl) 89: 303-315.

Devreese M, De Backer P, Croubels S (2013) Different methods to counteract mycotoxin production and its impact on animal health. Vlaams Diergeneeskundig Tijdschrift 82: 181-190.

European Commission (2006) Commission recommendation of 17 August 2006 on the presence of deoxynivalenol, zearalenone, ochratoxin A, T-2 and HT-2 and fumonisins in products intended for animal feeding. Off. J. Eur. Union 229: 7-9.

Fink-Gremmels $\mathrm{J}$ (2008) Mycotoxins in cattle feeds and carry-over to dairy milk: a review. Food Addit Contam Part A, 25: 172-180.

Fernandez A, Hernandez M, Verde MT, Sanz M (2000) Effect of aflatoxin on performance, hematology, and clinical immunology in lambs. Can J Vet Res 64: 53-58.

Gajecka M, Jakimiuk E, Polak M, Otrocka-Domagala I, Janowski T, Zwierzchowski W, Obremski K, Zielonka L, Apoznanski J, Gajecki M (2004) Zearalenone applied per os provides adverse effects in structure of chosen parts of bitch reproductive system. Pol J Vet Sci 7: 59-66.

Khatoon A (2012) Ruminal microflora, mycotoxin inactivation by ruminal microflora and conditions favouring mycotoxicosis in ruminants: a review. Inter $\mathrm{J}$ Vet Sci 1: 37-44.

Korosteleva SN, Smith TK, Boermans HJ (2007) Effects of Feedborne Fusarium Mycotoxins on the Performance, Metabolism, and Immunity of Dairy Cows. J Dairy Sci 90: 3867-3873. 
Mallmann CA, Dilkin P, Mallmann AO, Tyska D (2009) Mycotoxin: impacts and control strategies. Zopollato M, Muraro GB and Nussio LG (eds) In: Proceedings of International Symposium Forage Quality Conservation. Fundação de Estudos Agrários Luiz de Queiroz (FEALQ), Piracicaba, SP, Brazil, pp 269-280.

Mansfield MA, Kuldau GA (2007) Microbiological and molecular determination of mycobiota in fresh and ensiled maize silage. Mycologia 99: 269-278.

Marczuk J, Obremski K, Lutnicki K, Gajęcka M, Gajęcki M (2012) Zearalenone and deoxynivalenol mycotoxicosis in dairy cattle herds. Pol J Vet Sci 15: 365-372.

Morgavi DP, Riley RT (2007) An historical overview of field disease outbreaks known or suspected to be caused by consumption of feeds contaminated with Fusarium toxins. Anim Feed Sci Tech 137: 201-212.

Pier AC (1992) Major biological consequences of aflatoxicosis in animal production. Anim Sci 70: 3964-3967.

Purwin C, \$aniewska-Trokenheim \$, Warminska-Radyko I, Tywonczuk J (2006) Silage quality: microbiological, health-promoting and production aspects. Med Weter 62: 865-869.

Rasmussen RR, Rasmussen PH, Larsen TO, Bladt TT, Binderup ML (2011) In vitro cytotoxicity of fungi spoiling maize silage. Food Chem Toxicol 49: 31-44.

Sutkevičius J (2003) Veterinary clinical diagnostic (In Lithuanian). Kaunas: Naujasis lankas, pp 41-217.
Seeling K, Lebzien P, Danicke S, Spilke J, Sudekum KH, Flachowsky G (2006) Effects of level of feed intake and Fusarium toxin-contaminated wheat on rumen fermentation as well as on blood and milk parameters in cows. J Anim Physiol Anim Nutr 90: 103-115.

Smith TK, Diaz-Llano G, Korosteleva SN, Yegani M (2007) Significance of feed-borne Fusarium mycotoxins on livestock health and reproduction. In: Aland A and International Society for Animal Hygiene (eds) Proceedings of the 13th International Congress in Animal Hygiene: „Precision livestock farming - health and welfare aspects”. Vol I, Tartu, Estonia, pp 698-694.

Tripathi MK, Mondal D, Karim SA (2008) Growth, haematology, blood constituents and immunological status of lambs fed graded levels of animal feed grade damaged wheat as substitute of maize. J Anim Physiol Anim Nutr 92: $75-85$

Vahedi G (2012) Effect of Fusarium Contaminated Diet on Innate and Adaptive Immune Response in Rabbit Model. American-Eurasian Journal of Toxicological Sciences 4: 36-40.

Whitlow LW, Hagler WM (2002) Mycotoxins in feeds. Feedstuffs 74: 1-10.

Whitlow LW, (2005) Molds and Mycotoxins in Feedstuffs - Prevention and Treatment. Proceedings of the 16th Annual Florida Ruminant Nutrition Symposium, pp 123-142. 